\title{
STUDI PENDAHULUAN: RIWAYAT VAKSINASI BCG PADA PASIEN ANAK DENGAN TUBERKULOSIS PARU
}

\section{Hendra Kurniawan}

(Tropical Disease Research Center, Faculty of Medicine Khon Kaen University, Thailand, E-mail: hendrakurniawan@unmuhjember.ac.id)

\begin{abstract}
ABSTRAK
Infeksi tuberkulosis (TB) masih menjadi masalah kesehatan global, termasuk di Indonesia. Peningkatan munculnya strain Mycobacterium tuberculosis yang luas, ekstrim, dan resisten terhadap obat telah menghambat upaya pemberantasan patogen ini sehingga menyebabkan morbiditas dan mortalitas yang signifikan. WHO telah memprioritaskan strategi baru untuk meningkatkan program vaksinasi yang lebih baik, namun kurangnya pemahaman tentang imunitas mikobakterial membuat sulit untuk mengembangkan vaksinasi baru. Saat ini, Mycobacterium bovis bacillus Calmette-Guerin (BCG) adalah satu-satunya vaksin yang diterima untuk digunakan dalam pencegahan infeksi TB. BCG sangat berpengaruh dalam mencegah TB meningeal dan milier, namun hanya efektif $60 \%$ terhadap perkembangan TB pada orang dewasa, dan berkurang/menurun seiring bertambahnya usia. Penelitian ini dilakukan dengan menggunakan desain deskriptif eksploratif yang bertujuan mengidentifikasi riwayat vaksinasi BCG pada anak usia 0-14 tahun dengan infeksi TB di Wilayah Kerja Puskesmas Sukowono Jember. Hasil yang didapat pada penelitian ini adalah seluruh responden sebanyak 4 orang anak usia 0-14 tahun yang menderita infeksi TB dan memiliki riwayat vaksinasi BCG sebelumnya. Berdasarkan hasil studi pendahuluan ini, penelitian selanjutnya memerlukan area cakupan yang lebih luas sehingga dapat mengetahui lebih jelas efek atau hubungan vaksinasi BCG dengan kejadian infeksi TB pada anak dan/atau hubungannya dengan faktor pendukung lainnya seperti kondisi tempat tinggal atau infeksi penyerta, misal infeksi parasit khususnya cacing.
\end{abstract}

Kata kunci: Tuberkulosis Paru, Vaksinasi BCG, Anak.

\begin{abstract}
Tuberculosis $(T B)$ infection is still become global health concern including Indonesia. The increase of emergence of Mycobacterium tuberculosis strain that are extensive, extreme, and drug resistant inhibits eradication effort to this pathogen, leading to significant morbidity and mortality. New strategies prioritized by WHO to improve vaccination programs especially new vaccinations are difficult to develop due to lack of understanding in mycobacterial immunity. Nowadays, Mycobacterium bovis bacillus Calmette-Guerin (BCG) is the only accepted vaccine to prevent $T B$ infection since its potential to prevent meningeal and miliary $T B$, but it has been reported only $60 \%$ is effective in developing $T B$ in adults and decreases with age. This study conducted with a descriptive design which aimed to identify the history of BCG vaccination in children 0-14 years of age with $T B$ infection in the working area of public health center Sukowono
\end{abstract}


Jember. The results of this study were all respondents (4 children 0-14 years of age) who suffering TB infection, had a history of previous BCG vaccination. According to the result of this preliminary study, a broader scope of research is needed for further investigation so that it can determine more clearly about the effect or relationship of BCG vaccination to the incidence of TB infection in children and/or its relationship with other supporting factors such as living conditions and co-infection, such as parasitic infections particularly helminthes.

Keywords: Pulmonary Tuberculosis, BCG Vaccination, Children.

\section{PENDAHULUAN}

Tuberkulosis paru (TB) masih merupakan isu global meski upaya pengendalian dengan strategi DOTS (Directly Observed Treatment, Short-course) telah diterapkan sejak tahun 1995 (RI 2014). TB merupakan penyakit yang sebenarnya dapat dicegah dan disembuhkan namun ironisnya jumlah kasus dan kematian karena TB tetap tinggi meskipun laporan menunjukkan keberhasilan dalam pengendalian TB. Menurut WHO (2013) diperkirakan terdapat 8,6 juta kasus TB dengan HIV positif dan $75 \%$ dari angka total tersebut berada di Afrika. Kasus TBMDR (TB Multiple Drugs Resistance) pada tahun 2012, diperkirakan sebanyak 450.000 penderita dan $38 \%$ dari total kasus tersebut meninggal dunia. Masih pada tahun 2012, proporsi kasus TB anak per tahun diantara seluruh kasus TB global diperkirakan mencapai $6 \%$ atau sekitar 530.000 penderita dan angka mortalitas per tahun pada anak TB dengan HIV negatif mencapai 74.000. Menurut data tahun 2010, proporsi kasus TB anak diantara semua kasus TB sebesar 9,4\%, dan menurun pada tahun 2011 sebesar $8,5 \%$ dan $8,2 \%$ pada tahun 2012. Berdasarkan data per provinsi, variasi proporsi dari $1,8 \%$ hingga $15,9 \%$ menunjukkan kualitas diagnosis TB pada anak masih sangat bervariasi di level provinsi (RI 2014). Peningkatan angka insiden TB secara global telah berhasil dihentikan dan menunjukkan kecenderungan menurun sebesar $2 \%$ per tahun pada tahun 2012. Hal serupa pada angka kematian juga mengalami penurunan sebanyak $45 \%$ bila dibandingkan dengan tahun 1990 (RI 2014).

TB pada anak umumnya terjadi pada rentang usia 0-14 tahun dengan beberapa faktor penularan, antara lain: (1) tertular dari pasien dewasa atau anak dengan TB paru positif; (2) lama pajanan dan status imunitas anak. Status Basil Tahan Asam (BTA) positif pada pasien TB menyebabkan risiko penularan $65 \%$ lebih besar jika dibandingkan dengan BTA negatif kultur positif yang hanya sebesar 26\%. Tingkat penularan $17 \%$ terdapat pada pasien TB dengan hasil kultur negatif dan foto toraks positif. Minimnya alat diagnostik yang "child friendly" dan sistem pencatatan dan pelaporan kasus TB pada anak yang kurang memadai menjadikan beban kasus TB pada anak secara global tidak diketahui. Peningkatan dampak negatif pada morbiditas dan mortalitas anak disebabkan oleh banyaknya pasien TB anak yang tidak mendapatkan penatalaksanaan secara tepat dan benar sesuai ketentuan strategi DOTS (RI 2014). Penatalaksanaan klinis yang tersedia 
untuk memerangi TB meliputi agen kemoterapi dan vaksin pencegahan dengan Mycobacterium bovis bacillus Calmette-Guerin (BCG). BCG adalah strain dari $M$. bovis yang dilemahkan dan dikembangkan untuk mencegah infeksi TB. Vaksinasi BCG sangat efektif untuk mencegah meningitis TB dan penyebaran TB ekstra paru, namun efikasi (kemanfaatan) terhadap TB paru pada beberapa populasi (anak, remaja, dewasa, dan lansia) bervariasi. Beberapa studi menunjukkan $80 \%$ efektif, namun studi lainnya menunjukkan tidak adanya efikasi terhadap vaksinasi BCG (Kaufmann et al. 2010) (Colditz et al. 1994). Efikasi buruk yang ditunjukkan oleh vaksin BCG dalam mencegah infeksi TB berhubungan dengan banyak faktor, antara lain genetik dari pejamu (manusia) dan agen (Mycobacterium $S p p$ ), pajanan terhadap lingkungan Mycobacterium, koinfeksi dengan virus dan/atau parasit, letak geografis, dan yang terpenting adalah faktor nutrisi dan sosioekonomi (Fine, 1995) (Moliva et al., 2015). Namun, pertanyaan mendasar tetap pada apa yang membentuk pertahanan tubuh terhadap infeksi TB, dan mengapa BCG gagal

\section{HASIL PENELITIAN}

Berdasarkan observasi yang dilakukan di Puskesmas Sukowono Jember didapatkan data umum memberikan perlindungan terhadap infeksi TB itu sendiri. Masih belum jelas mengapa vaksin BCG gagal memberikan infeksi primer, reaktivasi, dan PTB (pulmonary tuberculosis), namun secara luas diterima bahwa sangatlah penting menghasilkan kekebalan protektif jangka panjang.

\section{METODE PENELITIAN}

Penelitian ini dilakukan dengan menggunakan desain deskriptif eksploratif yang bertujuan mengidentifikasi riwayat vaksinasi BCG pada anak usia 0-14 tahun dengan infeksi TB di Wilayah Kerja Puskesmas Sukowono Jember. Populasi dalam penelitian ini adalah seluruh pasien anak usia 0-14 tahun di Wilayah Kerja Puskesmas Sukowono Jember dalam rentang waktu tahun 2016-2017. Pengambilan data dilakukan pada bulan Mei 2018 menggunakan lembar observasi dengan checklist yang diverifikasi dengan KMS yang dimiliki pasien anak, sedangkan data infeksi TB didapatkan dari data rekam medis pasien berdasarkan hasil pemeriksaan/ diagnosis infeksi TB.

berupa usia dan jenis kelamin yang tersaji dalam tabel berikut ini.

Tabel 1 Karakteristik responden berdasarkan jenis kelamin

\begin{tabular}{ccc}
$\begin{array}{c}\text { Jenis } \\
\text { kelamin }\end{array}$ & Frekuensi & Persentase \\
\hline Laki-laki & 3 & $75 \%$ \\
Perempuan & 1 & $25 \%$ \\
\hline Jumlah & 4 & $100 \%$ \\
\hline
\end{tabular}


Kriteria yang ditentukan pada penelitian ini adalah responden anak yang berada pada rentang usia $0-14$ tahun, data karakteristik responden berdasarkan usia tersaji pada diagram berikut.

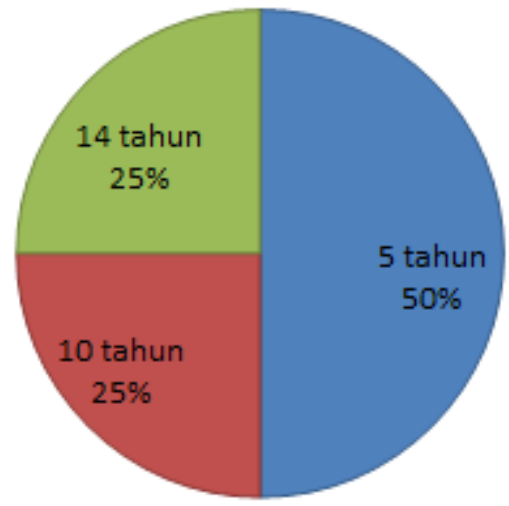

Gambar 1 Karakteristik responden berdasarkan usia

Berdasarkan penjelasan data umum diatas, dalam rentang waktu tahun 2016-2017 ditemukan angka kejadian infeksi TB pada anak usia 0-14 tahun di Wilayah Kerja
Puskesmas Sukowono Jember sebanyak 4 orang dan data khusus akan dijelaskan secara rinci pada tabel dibawah ini.

Tabel 2 Status infeksi tuberkulosis dan riwayat vaksinasi BCG

\begin{tabular}{cccc}
\hline Nama (inisial) & Tanggal ditemukan & Status TB & Riwayat vaksinasi BCG \\
\hline An. R & $15 / 02 / 2016$ & TB BTA neg & Ya \\
An. G & $14 / 09 / 2016$ & TB BTA neg & Ya \\
An. Z & $19 / 11 / 2016$ & TB BTA neg & Ya \\
& & (skor 8) & \\
An. N & $09 / 08 / 2017$ & TB EP & Ya \\
\hline
\end{tabular}

Tabel diatas memperlihatkan dari semua responden anak usia $0-14$

\section{PEMBAHASAN}

Secara prinsip konsep imunologi, saat tubuh menerima vaksinasi $\mathrm{BCG}$, fagositosis oleh makrofag dan sel dendritik memulai respon imun dari sistem imun nonspesifik melalui sekresi komponenkomponen imunomodulator seperti sitokin dan kemokin. Bakteri atau kuman terdegradasi melalui mekanisme pembunuhan intraseluler tahun yang menderita infeksi TB, pernah menerima vaksinasi BCG.

(intracellular killing mechanisms) dan peptida dari kuman selanjutnya akan menuju membran plasma bersama dengan Major Histocompatibility Complex (MHC) kelas I dan II yang akan dipresentasikan pada sistem imun spesifik. Neutrofil juga memasuki tempat inokulasi dan turut serta dalam respon imun. Pada akhirnya, sel dendritik penuh akan bakteri yang telah melewati respon imun non- 
spesifik dan mengekpresikan antigen pada permukaannya untuk menuju proses selanjutnya di nodus limfe.

Saat memasuki nodus limfe, sel dendritik menstimulasi CD4, CD8, CD1 restricted $T$ Cells, sel $\mathrm{T}$ regulator, dan sel $\mathrm{B}$. CD4 dan $\mathrm{CD} 8$ bermigrasi keluar dari nodus limfe menuju tempat inokulasi dan memberikan stimulasi yang diperlukan untuk sel-sel sistem imun non-spesifik. Sel T $\quad$ CD4 berdiferensiasi menjadi sel Th1, Th17, atau sel Th2, tergantung dari stimulus yang ada dan juga berfungsi membantu aktivasi makrofag, sedangkan sel $\mathrm{T}$ CD8 berfungsi untuk menghacurkan (lisis) sel yang terinfeksi dan mensekresi sitokin. Sel B berdiferensiasi menjadi antobodi dan memori sel B. Selama proses tersebut, sel memori muncul dari tempat/ lokasi yang terinfeksi dan berkumpul di organ-organ perifer, seperti paru. Di saat yang sama, selsel sistem imun spesifik mengatur respon imun dalam upaya membentuk kekebalan terhadap Mycobacterium (Moliva et al. 2017). Pada penelitian ini didapatkan data selama tahun 2016-2017 dari responden anak usia 0-14 tahun yang berjumlah 4 orang dengan infeksi TB, keseluruhan responden memiliki riwayat vaksinasi BCG sebelumnya.

Hasil tersebut seolah bertolak belakang dengan konsep imunologi yang dijelaskan pada paragraf diatas tentang bagaimana sistem imun tubuh kita berespon terhadap pemberian vaksinasi BCG, juga didukung oleh badan kesehatan dunia (WHO) yang menyatakan bahwa BCG merupakan satu-satunya vaksin yang diterima untuk digunakan dalam mencegah infeksi TB. Terlalu superfisial menyimpulkan jika vaksinasi BCG tidak memiliki efek protektif bagi anak untuk kemungkinan terinfeksi TB dimasa mendatang, namun setidaknya hasil studi pendahuluan (preliminary study) ini dapat dikembangkan untuk topik yang sama dengan penjabaran di beberapa faktor/variabel, tentunya dengan jumlah responden yang lebih besar dengan cakupan penelitian yang lebih luas.

Terdapat studi yang pernah dilakukan melalui percobaan pada hewan (animal model) yang memperlihatkan bahwa hewan yang dipaparkan pada environmental mycobacteria tertentu akan meningkatkan respon imun yang dapat mengontrol multiplikasi BCG sehingga mengurangi/membatasi perkembangan kerja vaksin BCG, dan paparan terhadap environmental mycobacteria dapat meningkatkan level proteksi perlindungan (protective immunity) terhadap mycobacteria jenis lainnya. Pendapat dari peneliti lainnya bahwa adanya kontak dengan bakteri nontuberkulosis memberikan proteksi perlindungan terhadap TB, sehingga efek perlindungan dari vaksin $\mathrm{BCG}$ akan tertutupi. Observasi terhadap environmental mycobacteria juga dilakukan pada pengamatan tuberculin skin test dimana rata-rata diameter indurasi jauh lebih kecil di area dengan environmental mycobacteria lebih banyak (daerah tropis) dibandingkan dengan area minimal paparan environmental mycobacteria (negara maju) (Brandt et al. 2002).

\section{SIMPULAN}

Pada penelitian yang dilakukan di Wilayah Kerja Puskesmas Sukowono Jember terdapat 4 orang 
anak usia yang terinfeksi TB dengan riwayat vaksinasi BCG sebelumnya, yang berarti seolah vaksinasi BCG tidak memberikan efek proteksi bagi anak terhadap infeksi TB di masa mendatang.

\section{SARAN}

Saran bagi puskesmas dan dinas terkait adalah perlunya dilakukan skrining lebih maksimal kembali mengenai kasus TB pada anak di masyarakat khususnya yang tinggal serumah dengan pasien TB. Untuk penelitian selanjutnya diperlukan area cakupan penelitian yang lebih luas sehingga dapat mengetahui lebih jelas efek atau hubungan vaksinasi BCG dengan kejadian infeksi TB pada anak dan/ atau hubungannya dengan faktor pendukung lainnya seperti kondisi tempat tinggal dan infeksi penyerta lainnya, misal infeksi parasit khususnya cacing.

\section{DAFTAR PUSTAKA}

Brandt, L. et al., 2002. Failure of the Mycobacterium bovis BCG vaccine: Some species of environmental mycobacteria block multiplication of BCG and induction of protective immunity to tuberculosis. Infection and Immunity, 70(2), pp.672-678.

Colditz, G.A. et al., 1994. Efficacy of BCG vaccine in the prevention of tuberculosis. Meta-analysis of the published literature. The Journal of the American Medical Association.

Fine, P.E.M., 1995. Variation in protection by BCG: implications of and for heterologous immunity. The Lancet.

Kaufmann, S.H.E. et al., 2010. New vaccines for tuberculosis. Lancet (London, England).

Moliva, J.I., Turner, J. \& Torrelles, J.B., 2017. Immune Responses to Bacillus Calmette-Guérin Vaccination: Why Do They Fail to Protect against Mycobacterium tuberculosis? Frontiers in Immunology.

Moliva, J.I., Turner, J. \& Torrelles, J.B., 2015. Prospects in Mycobacterium bovis Bacille Calmette et $\mathrm{Gu}$ ??rin (BCG) vaccine diversity and delivery: Why does BCG fail to protect against tuberculosis? Vaccine.

RI, K.K., 2014. Pedoman Nasional Pengendalian Tuberkulosis, Jakarta: Kementerian Kesehatan RI. 